\title{
中堅私学の学力向上とコスト意識を培うための 大学院教育及び卒論教育の研究と実践
}

Practical Education for Improving Academic Ability of Students at Middle Class Private University and Cultivating Cost Mind in Education Process

\author{
東忠 則*1 \\ Tadanori AZUMA
}

\begin{abstract}
Although now in a great confusion, our country should endeavor to be a truly first class nation, now that it has achieved the status of a big economic power. A nation of genuine leadership must realize and keep not only economic power but also high moral of its people, the author believes. On the other hand, our nation is poor in natural resources. Higher ability of research and development is, therefore, an indispensable requirement in order for us to realize and keep the status of genuinely first class. The author has tried to achieve minimum cost in R\&D in his career as an engineer and a teacher at a middle class private university. This paper reports the author's experience in improving academic ability of students and cultivating cost mind in education process.

Keywords : Engineering Education, Graduates, Academic Ability, Practical Study, Problem Solution, Experimental Planning, Research and Development, Cost Mind

キーワード : 工学教育, 大学院生, 学力向上, 実践教育, 問題解決, 実験計画, 研究開発, コスト意識
\end{abstract}

\section{1.はじめに}

筆者は 20 数年間，大企業で主にエンジン技術の研 究開発に従事した後, 約 2 年間は中小企業で研究開発 担当の役員をした。そして 1989 年 4 月中堅クラスの 私学に転じ，2000年 4 月に大学院（修士）が設置さ れてから大学院における研究指導を行っている。

他方，我が国は1960年代後半から 1980 年代半ばま での急速な高度経済成長によって経済大国と言われる ようになったが，1990年代に入って急速に経済力が 低下した。そして，先行きは今も不透明である。

筆者は我が国がこの状況を克服するには，真の一流 国家を目指すべきであると考えて，筆者の足元ででき る範囲で努力して来た，その一環として教育現場の歪 み是正に努力してきた11-7). 真の一流国家には，国民 の民度の高さと適度の経済力は車の両輪であり, 天然 資源にそしい我が国では，新技術開発力は国力を維持 するために必須の要件であろう。他方，技術開発を進 めるには成功の見通しを得るための，予備的な試験研 究が必要でありコストを要する，本報では企業におけ る筆者の体験を基に，研究開発の見通しの段階で，コ ストを最小にする教育，ならびに，中堅私立大学にお ける学生の学力向上の研究と実践について報告する.

平成 15 年 10 月 31 日受付 ※1 (元) 帝京大学理工学部
筆者は本来実学指向であるが，奉職している大学の建 学の精神のひとつも実学である. 世論も実学大学院を 求めている8).

\section{2. 実学とは何か}

実学について学問的な定義があるかどうか筆者は知 らない。ここでは筆者が大学を終えてから約 30 年間, 実務に従事した経験に基づいて実学の概念について述 ベる。

筆者は実学を実際の業務や日常生活に必要な学問と 理解している. そして学問は現状で認められている法 則または理論と理解している.大企業でエンジンの研 究開発や設計に従事した筆者にとっては，材料力学， 機械力学, 流体力学, 熱力学をはじめとする機械工学 の専門科目や, 数学, 物理学, 語学は実学であり, 新 入社員には大学のテキストにある程度のことは，でき るだけ身につけていることを希望した. 文章力も重要 である，とにかく，できるだけ広い範囲で学力が高い 新卒者を望んだ.

2 年間勤務した中小企業は，その分野では技術レ ベルの高い企業であったから，大企業の新卒者と同 程度の学力を持つ新卒者が望ましかったが，採用し 得るのは中堅私学の新卒者であった。そして大企業 で採用した新卒者と中小企業のそれには，学力に招 いて大きな開きがあることを知った，彼等には数式 
を用いた理論解析はほとんど期待できない。そこで 中堅私学における実学は, 数式なしの定性的な理論 にならざるを得ないことを知った。語学もほとんど 期待できない.

ここで実学についての誤った認識を指摘しておきた い. 大学だけで育った教員には，実学を skill と勘違 いしている人が割合に多い。これは学問を実務で用い た経験が少ないための誤りと思われる.

\section{3. 設計と研究開発で要求される学問のレベル}

3. 1 設計は学問を基礎にしている

エンジンを例にとろう. 従来とは異なる新機種の設 計があるとする，ピストン直径 $\mathrm{D}$ ，ストローク $\mathrm{S}$ ，両 者の比 $\mathrm{S} / \mathrm{D}$, およびシリンダ数等が異なるとしよう. 連接棒だけをとりあげてもその寸法，形状，材料を決 定するのに機械力学, 材料力学, 材料強度学が縦横に 駆使される. エンジン全体の計画では熱力学, 流体力 学, 振動論, 機構学, 伝熱工学, 潤滑理論等, 機械工 学の広い分野における, 最新の研究成果が応用される. 寸法や構造は, 理論計算とこれまでの経験やデー夕に よって決定される。

\section{2 改善のための研究開発}

現在の工業化社会は18世紀におけるイギリスの産 業革命から始まった。これはエンジンの発明がひき金 になっている．したがってエンジンは機械の中でも歴 史が古く研究開発の歴史が長い. そのために現在の工 ンジンの研究開発は, 小さな改善研究の積み重ねと言 っても過言ではない，機械技術全般がほぼ同じような 状況であろう。このような研究開発ではまず定量的な 理論解析によって見通しを得て，実験によって検証す るやり方が主流になっている。ここでも高度の学問が 基礎である。

\section{3 独創的なアイディアによる研究開発}

研究開発が独創的であるほど，その分野の学問は未 開拓であるから, 理論式は全くないか, 簡単なものに なる、また，実験装置は簡単なもので価值ある結果を 得ることができる、筆者は某企業の社長が発明した独 創的な技術の基礎研究を通じて，上記のようなことを 体験している.

\section{4. 中堅私学における学力の実態と向上策 \\ 4. 1 学力の実態}

筆者は企業時代に新卒採用にも携わった。また新卒 社員の学カレベルには常に関心を持っていた．筆者の ように大企業の設計・研究開発に従事した立場から, 一流大学の目安は, その大学の大学院 (修士) 終了者 を優先的に採用できるか否かということであった.こ れは, 一流大学の大学院生は高い学力で選抜され, 研 究計画から報告のまとめまで一応の訓練を受けている ので，企業における研究開発業務を担当させるまでの
手間が比較的省けるのと, 定量的な理論解析が要求さ れる改善研究の戦力として有力と考えたからであり, 実際にそうであった。

そこで筆者は現在勤務している中堅私学の精鋭養 成コースとして, やる気のある学生のための演習コ 一スを 3 年生に設けて筆者が担当し，機械工学の基 礎学力を向上させることを目指してきた.そして, この中からできるだけ多くの学生が大学院へ進学し, 一流企業へ就職できるように指導し，それは概ね成 功している.

演習コースに最後まで残る学生のほとんどは, 学 業成績がトップクラスの学生である.しかし，この 学生群の学力は英語と数学に限れば, 筆者の中学 3 年の時のそれに及ばないところが多々ある。たとえ ば筆者は 3 角関数 $\sin \theta, \cos \theta, \tan \theta$ の幾何学的概 念は中学 3 年の時に正確に理解していたし, 曲線の 描き方も原理を正確に理解していた。それは頭で理 解するというよりも，作図の作業で身につけた。 ま た $\sin ^{2} \theta+\cos ^{2} \theta=1$ は，ピタゴラスの定理の応用で あるから，ほとんどむずかしいとは思わなかった． ところが，ある年度の演習コース 10 人余の 3 年次生 で，年度初めに上記のことが満足にできたのは 1 名 に過ぎない. 筆者は $\pi$ の意味は小学校 $3 \sim 4$ 年の時 に丸太にひもを巻きつけて, 円周と直径の比である ことを理解した。また， $2 \mathrm{r}$ を 1 辺とする正方形と， $\mathrm{r}$ 半径とする円の面積比が 4 ： $\pi$ であることも作図 の作業によって正確に理解していた。ただし半径は $\mathrm{r}$ の記号ではなく数字を用いた。高校では積分計算


した，そして円周率が角度の単位としてのラジアン に由来することを知った。演習コースの学生で $\pi を$ 円周と直径の比と理解していた者は 1 名あったが, 面積比と理解していた者は 1 人もなかった。

英語でHe like dogsで, likesでなければならない と答えた者は 1 人いたが，何故 likesかについては 1 人も答えられなかった。これは筆者の中学 1 年生の時 の問題である. 以上が中堅私学における学力の実態で ある。

\section{2 学力向上策}

筆者の経験では, 小中学の成績中位以下はおしな べて勉強ぎらいであった。現在, 大学進学率は約 $50 \%$ あるが, 大学への入学志願者は高校の学業成 績上位から下位まで分布している，中堅クラスの私 学では, ほんとうに勉学の意欲があるのは $10 \%$ 程度 と言われており，筆者の体験でもその通りである. これは, 元来勉強ぎらいな学生が入学しているから であろう。

やる気のある約 10\%の学生の学力が上記の通りで ある．学生に自信を失わせてはいけないが，実情をあ りのまま認識させる必要がある. 学力が低い原因のひ 
とつは，小中高での教え方に問題があるように思われ る. 筆者が数学, 物理学, 化学, 英語等の基礎をてい ねいに教えると, ほとんどの学生がよく理解するから である．そこで学力向上策としては，（1）基礎の中の 基礎に焦点を絞る。（2）ていねいな授業で基礎が分か るようにする.（3)筆者等の同じ年代に比べて現代の 学生の学力が低いのは, 特に初歩的, 基礎的な段階で 生徒に分かるような教え方になって抢らず，(4)その ためにその後の段階が分からなくなり, 勉強ぎらいに なっているようにおもわれることや，(5)普通の人間 の頭脳には大差がないことを実例で示して自信を失わ ないようにすると共に，（6)頭の良し悪しではなく， やるかやらないかで差がつくこと，（7) 筆者は自分に 能力がないことを知っているので一流を目指して，せ めて普通になるために普通の人の何倍も努力して来た ことを,くり返し説明している.

\section{5. 教育過程でコスト意識を培う教育の実践 \\ 5. 1 コスト意識を持たせる教育の必要性}

筆者の学科では学部, 大学院ともにほとんどの学生 が, 卒業後の職種として研究開発を希望する.これは 一種の流行かも知れないが, 我が国の技術開発力向上 のためには,この風潮を育成し定着させねばならない. 生産や研究開発費を最小にすることは，大局的にはそ れ自体が省資源と環境保全に寄与するので，企業の大 小を問わず重要である.

筆者の経験では，大企業と中小企業では資金力と人 材において，規模の比率以上の差があるので, 中小企 業では研究開発費を最小にする努力と工夫が特に重要 である．中堅私学の卒業生の多くは中小企業に就職す る.したがって，中堅私学ではコスト意識を持たせる 教育が特に重要と考えている.

\section{2 コスト意識を持たせる教育法の基本方針}

中堅私学の新卒者は理論解析によるシュミレーショ ンを行う能力にそしく，就職先でもそのような訓練が 行われることは期待できない。そこで筆者は教育の方 針をつぎのようにしている.（1）よく調べることによ って，これから取り組む技術的な問題の原理をよく理 解する.（2）それを通して問題へアプローチする定性 的な理論（仮説）を持つ．（3)できることは何でも自 分の手でやる. (4) 実験装置や用具は原則としてあり 合わせのもので間に合わせる.（5）無いものは購入す るのでなく，できるだけ手作りにすることを原則とす る.

上記の原則から外れると，大学で行う実験でも費用 は膨大になり実行不能となる，企業では装置が大きく なるのでなおさらである. 次節で具体例を示す.

5. 3 コスト意識を持たせる教育の実例（その 1 ）

2001 年度の大学院新入生で, 筆者の研究室ではこ れまでやったことのない，ロータリエンジン
の研究を希望する学生があったので，これをスタート させた．以下，修士論文をまとめるまでの最小コスト を目指した経緯を示す。

\section{(1) RE車の購入}

インターネットで全国の中古車を調査させた．約 6 万円の中古車があったが最小限 3 年間, 数人で使用す ることになるので許可した。

\section{(2) エンジン組立台}

車からエンジンを外して構造や原理を知るのに組立 台が必要である，学生の計画に任せたところ，外注費 約 30 万円の見積りを持って来た，筆者はこの時，は じめて前述のような方針を示し，企業の研究開発者は 費用をどこまで少なくできるかによって，研究開発者 としての能力が測られることを説明した，そして，こ れを学科の工場で自作して見積りの $1 / 10$ 以下にす るように指示し，その通りとなった。

\section{（3）ガス流れ実験の模型装置製作}

この学生は文献と実物でREについての総合的な研 究の中から, 要素研究として燃焼室内のガス流れの実 験を申し出た。これも計画を本人に任せたところ，エ ンジン模型，計測装置を含めればおそらく200万円程 度になったと思われる。

$\mathrm{RE}$ の形状は外観は単純であるが，数学的には比較 的複雑である．筆者はこの学生に機械工場の助けを 借りて，すべて自分の手で削り出すように指示した． 自分で削り出しが出来なければ，筆者がやってみせ るから申し出よと指示した。 その結果，短期間に見 事な模型装置を製作した。製作過程では要求に合う 市販の歯車がないので，特別作製の発注を何回か申 し出て来た。筆者は歯車は最も基本的な機械要素の ひとつであり, 要求にぴたりか, それに近いものは 必ずあるから，自力で探し出すように指示した。そ して研究開発者がやる仕事の大半はそのようなもの であることを説明した．結局，約 500 円の歯車を見出 した.

ガス流れの計測は，最初はむずかしいことを考えず に煙を流して目視で観察し，記録するように指示した。 結局，ガス流れの実験は装置と計測を含めて $3 \sim 4$ 万 円程度であった。

\section{(4) REの形状に関する数学的研究}

$\mathrm{RE}$ のケーシングはマユ形の曲線である，その中を おむすび形のロータが回転する. せっかく数学や歯車 の勉強をするよい材料を持っているのであるから，理 論的な研究を行うよう指示した。 ガス流れ実験用の工 ンジン形状は,この研究の中で決定されたものである. エンジン形状を REの標準形と，標準形からの変形を 1 種選定し, 両者を理論的に比較して, 標準形が総合 的に秀れていることを，理論とガス流れに関する実験 結果の両面から考察している. 中堅私学における修士 論文としては優れている. 
5. 4 コスト意識を持たせる教育の実例（その 2) 前記の例は改善研究に属する学生教育の例である. ここでは独創的なアイディアによる breakthrough 型 新技術に関する基礎実験の 1 例を示す．要点は，この ような技術開発に関する基礎実験では，学部学生が簡 単な道具を用いた実験で，国際学会で発表できる結果 が得られるところにある.

筆者は企業時代に知り合った中小企業の社長による 新技術,「エンジンオイルの半永久使用と廃油ゼロ技 術」の研究開発と実用化の支援を行っている。この技 術は世界の常識を覆した独創的な技術であり ${ }^{93,10)}$, 省 資源と環境保全に大きく寄与している。すでに 1000 台以上の舶用とコジェネ用ディーゼルで実用されて おり，予想以上の成果をあげている．新しい技術で あるから, 理諭体系を固める基礎研究も必要であ る。

エンジンオイル（LO）には各種の添加剤が用いら れており，清浄分散剤と酸化防止剂が最も多く用いら れている. 従来の LO浄化技術ではこれは必要不可欠 であろう。しかし筆者等が研究している新技術（Kidney system) では, この 2 種の添加片はむしろ不要 有害である．他の添加剤も不要有害と考えている．こ れを実証する実験で用いた装置は, 高さ約 $0.5 \mathrm{~m}$ の簡 単なLO循環器だけである。これは共同研究の企業か ら提供してもらった。この実験結果は日本マリンエン ジニアリング学会と自動車技術会で学生が発表した. このまま国際学会で発表できるが, 若干補足して 2004年に国際学会で発表する予定である。

この学生は入学直後に勉学を意り, 前期の取得単位 はゼロであったが，筆者が推進してきた個別指導によ り，意欲を拡幅した：卒業研究では筆者の研究室へ配 属された，筆者の指導，励まし及びよい先輩との組み 合わせで上記の研究発表をすることができた，筆者が アメリカ留学を奨めて手配し，2003年 3 月に渡米し て目下留学中である.

\section{6.一流を目指すと共にコスト意識を培う教育の 成果}

本報では具体例を 2 例示したが，筆者は基本的に上 記のような教育を続けている，教育は経験の積み重ね である.毎年の経験を基に改善してきたつもりである.

$\mathrm{RE}$ の研究を提案し担当したのは女子大学院生であ る。一般的に女子学生は就職に不利であるが，これを はね返して，一流企業に就職できるようにするため, この女子学生は特に厳しく訓練した. その結果この学 生は（1）課題に積極的に取り組み，（2）指示や助言 を素直に受け入れ，（3)訓練のつもりで意識的にきび しくしても感情的に反発することがなく，（4）礼儀正 しい，というところが定着し，（5）これが他の学生へ の模範になった.
かなりの期間にわたる紂余曲折はあったが，この女 子大学院生は, 遂に某一流企業 A 社に合格し入社し た。本来の優れた資質と，一流を目指した筆者の訓練 の相乗効果であろう．A社への入社は恐らく筆者の学 部では最初であろう。もう 1 人の大学院生も有名一流 企業へ入社し, 他の 5 人の大学院生もかなりの企業に 入社した。前年の 2001 年度は大学院の第 1 回終了生 で筆者の研究室から, 自動車のトップメーカN社に入 社した. 本学部から N社へ最初の合格者であろう. 続 いて 2002 年度は学部学生から $\mathrm{N}$ 社に入社した。筆者 は常に筆者の能力以上を目指して来た。 そうすると周 囲から優秀な人材が現れる.

1989 年 4 月に大学に転じてからは, 筆者は我が 国が真の一流を目指す一環として, 筆者の大学が一 流を目指すように提唱してきた ${ }^{3}$. そして筆者の学 科や研究室でできる範囲のことは, あらゆることを 試みてきた。そのひとつとして学科長職にあった 1993 年から 2002 年までの 10 年間は, 欠席が多いと か, 取得単位の少ない要注意の学生を個別に指導し て, 留年や退学を最少にすることに力を入れてき た。また, 筆者の研究室や, 筆者が1998年から始 めた精鋭養成コースの機械工学演習の履修者の中か ら, 一人でも多く一流企業へ就職させることを目指 してきた。 そして成果は予想以上に現れたと考えて いる.

\section{7. むすび}

真の一流国家を目指す教育のひとつとして, 中堅私 学に扔ける学生の学力の向上と, コスト意識を培う教 育の実践例を示した. 以下に本研究の結果をまとめる.

（1）中堅私学における学生の学力は低い. しかし, 教員が情熱を持って指導して学生のやる気を引き 出せば, 学生の勉学意欲が高まり, 短期間で予想 以上に学力が向上する.

（2）入学直後に生活が乱れ，勉学意欲を失っている 学生も, 愛情と熱意を持って指導し, よき先輩や 友人と組み合わせることによって短期間に立ち直 り,たとえば大学院進学を目指したり, 海外留学 を実現するところまで勉学意欲が高まる。

（3）コスト意識を持たせるため実験研究等では, 最 小コストを目標にして具体的な方針を示し，これ を徹底的に追求することで学生の創意工夫が生ま れ，成果を出すことにより自信がつく、それによ って人物，学力ともに向上する.

（4）総括すれば，指導者が明確な目標を持ってやれ ば必ず結果は現われ，よりよい教育法を編み出す ことができる。そして真の一流国家形成に，この ような教育法の研究と実践が不可欠と信ずる. 


\section{参考文 献}

1) 東 忠則：やる気一流を目指した実学教育の研究 と実践, 日本工学教育協会, 工学・工業教育研究 講演会 (2001.7.18), 講演論文集, $75-78$

2 ) 東 忠則: 大衆化大学の現状と将来あるべき姿, 日本産業教育研究会研究紀要, 30 (1999.5 .25), $27-46$

3 ) 東 忠則：真の一流国家とやる気一流の大学を目 指して, 日本産業教育研究会研究紀要, 31 (2002. $5.25), 31-82$

4 ) 東 忠則：社会の浄化と正常化を目指す研究と害 践 (1) 一教育現場における歪と公開による是正一, 日本工学教育協会, 工学 - 工業教育研究講演会 (2002. 7.20), 講演論文集, $127-130$

5 ) 東 忠則：社会の浄化と正常化を目指玄研究と実 践 (2) 一教育現場における正義実現への執念一, 日本機会学会 2002 年度年次大会 $(2002.9 .25$ ～ 27）講演論文集，№. $02-1 ， 417-418$

6 ) 東 忠則：社会の浄化と正常化を目指す研究と害 践 ( 3 ) 一倫理欠如による技術教育現場の歪みと是 正への執念一, 日本機械学会講演会, 技術と社会 の関連を巡って, 京大会館, 講演論文集 (2002. 10. 19), $25-28$

7 ) 東 忠則 : 社会の浄化と正常化を目指す研究と実 践 (4) 一教育現場の歪み是正への兆しと今後の展 望一日本機械学会関東支部第 9 期総会 ·講演会 (2003. 3 .14), 講演論文集, 技術教育·工学教育,
№. $030-1,311-312$

8 ）讀賣新聞, 2003. 1.16(木), 朝刊, 社説：実学大 学院，世界に通用する職業人を育てよ

9 ）東，住本，木村：世界の常識を覆した技術開発に おける産学協同の成果, 日本フルートパワーシス テム学会誌, $33-2(2002.3), 31-34$

10) T. Azuma, M. Sumimoto and I. Kimura, “A study on nearly non-oxidation characteristics of lubricating oil and a new lub and fuel oil system for semi-permanent use of lub oil, no waste oil and higher reliability in marine diesel engines." 23rd CIMAC World Congress, 2001, May $7 \sim 10$, Humburg. Germany, Proceedings Vol. 3, $1180-$ 1195

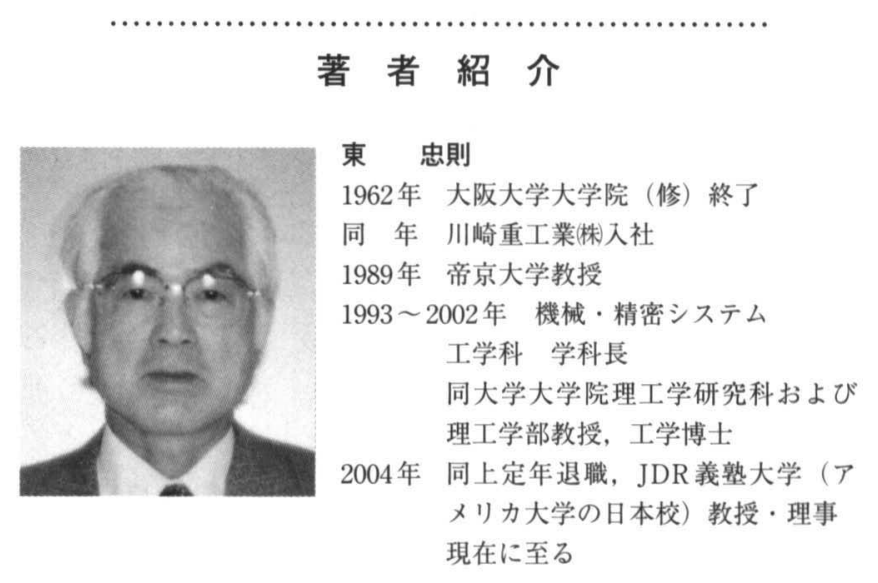

